\title{
Effect of berberine on lipopolysaccharide-induced monocyte chemotactic protein-1 and interleukin-8 expression in a human retinal pigment epithelial cell line
}

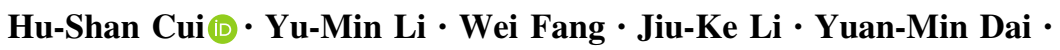 \\ Lian-Shun Zheng
}

Received: 27 April 2017/Accepted: 18 August 2017/Published online: 29 August 2017

(C) The Author(s) 2017. This article is an open access publication

\begin{abstract}
Purpose In this study, we elucidated the effects of berberine, a major alkaloid component contained in medicinal herbs, such as Phellodendri Cortex and Coptidis Rhizoma, on expression of monocyte chemotactic protein-1 (MCP-1) and interleukin-8 (IL-8) in a human retinal pigment epithelial cell line (ARPE-19) caused by lipopolysaccharide (LPS) stimulation.

Methods ARPE-19 cells were cultured to confluence. Berberine and LPS were added to the medium. MCP-1 and IL- 8 mRNA were measured by real-time polymerase chain reaction. MCP-1 and IL- 8 protein concentrations in the media were measured using enzyme-linked immunosorbent assay.

Results After stimulation with LPS, MCP-1 and IL-8 mRNA in ARPE-19 cells reached maximum levels at $3 \mathrm{~h}$, and MCP- 1 and IL- 8 protein in the culture media reached maximum levels at $24 \mathrm{~h}$. Berberine dosedependently inhibited MCP-1 and IL-8 mRNA
\end{abstract}

H.-S. Cui $(\bowtie) \cdot$ Y.-M. Li · W. Fang ·

J.-K. Li · Y.-M. Dai

Department of Ophthalmology, Affiliated Sir Run Run

Shaw Hospital, School of Medicine, Zhejiang University,

No. 3 Qingchun Road East,

Hangzhou 310016, Zhejiang Province, China

e-mail: cuihushan@hotmail.com

\section{L.-S. Zheng}

Institute of Anatomy and Cell Biology, School of

Medicine, Zhejiang University, Hangzhou, China expression of the cells and protein levels in the media stimulated with LPS.

Conclusions These findings indicate that berberine inhibited the expression of MCP-1 and IL-8 induced by LPS.

Keywords Berberine $\cdot$ Human retinal pigment epithelial cells $\cdot$ Lipopolysaccharide $\cdot$ Monocyte chemotactic protein- $1 \cdot$ Interleukin- 8

\section{Introduction}

The retinal pigment epithelial (RPE) cells play important roles in physiology of the retina. The main functions of RPE are phagocytosis of photoreceptor segments, absorption of light, and formation of blood-retina barrier, which regulates the ionic and metabolic gradients required for normal retinal function [1]. The RPE cells also have an important role in different pathologic processes of the retina such as age-related macular degeneration and diabetic retinopathy [2-5]. Human RPE cells isolated from donor eyes express monocyte chemotactic protein-1 (MCP-1) and interleukin-8 (IL-8) by stimulation with lipopolysaccharide (LPS) [6, 7]. MCP-1 is a potent chemoattractant inducing the infiltration of monocytes and macrophages into tissues [8]. IL-8 is known as a neutrophil chemotactic factor [9]. MCP-1 and IL-8 are member of 
two chemotactic families [10] and are called CCL2 and CXCL8, respectively, according to a new classification system recommended by Zlotnik and Yoshie [11]. Crane et al. [12] reported that MCP-1 and IL- 8 are produced at much higher levels than other chemokines tested in RPE cells. Dunn et al. [13] reported that ARPE-19, a human retinal pigment epithelial cell line, has structural and functional properties characteristic of RPE cells in vivo. Our study showed that MCP-1 and IL-8 in the culture media of ARPE-19 cells are increased by IL-1 $\beta$ or TNF- $\alpha[14,15]$. LPS induced MCP-1 and IL-8 in ARPE-19 cells [7, 16, 17]. The levels of chemotactic cytokines including MCP-1 and IL-8 are higher in the vitreous of patients with agerelated macular degeneration [18-20], proliferative vitreoretinal diseases [21, 22], and proliferative diabetic retinopathy than in normal subjects [23-25]. These cytokines may help in stimulating the infiltration of monocytes and macrophages into eyes with such disorders [26]. Thus, MCP-1 and IL8 may be involved in part in the pathogenesis of intraocular disorders.

Berberine (Fig. 1) is a major alkaloid isolated from medicinal herbs such as Berberis sp., Coptidis sp. rhizome, and Phellodendri sp. cortex; these plants are included in several Kampo formulae (traditional Chinese-Korean-Japanese medicine), such as Orengedoku-to (Huang-Lian-Jie-Du-Tang), and have been used to treat various inflammatory diseases. This alkaloid has multiple pharmacological actions, including diarrhea-treating action [27-29], anti-inflammatory effects [15, 30-36], glucose-lowering potential [37-40], cholesterol-lowering effect [41-43], and neuroprotective action [44-47]. We previously reported that berberine inhibited MCP-1 and IL- 8 induced by LPS in rat uveitis in vivo [36]. In the present study, we investigated the effects of berberine

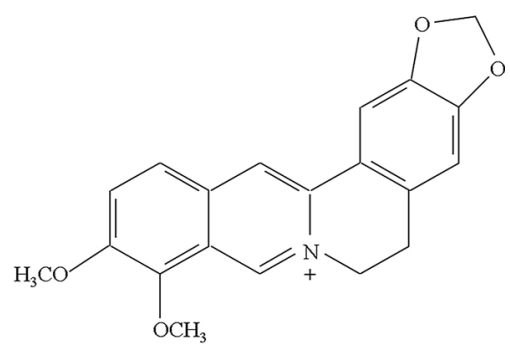

Fig. 1 Chemical structure of berberine on MCP-1 and IL-8 expression in ARPE-19 cells stimulated with LPS.

\section{Materials and methods}

Cell culture

ARPE-19, a human RPE cell line, was purchased from American Type Culture Collection (No. CRL-2302, Rockville, MD, USA). The cells were maintained in Dulbecco's modified essential medium and Ham's F12 (DMEM/F12; 1:1; Gibco-BRL, NY, USA) supplemented with $10 \%$ fetal bovine serum (FBS); penicillin, $100 \mathrm{U} / \mathrm{ml}$; and streptomycin, $100 \mu \mathrm{g} / \mathrm{ml}$, to obtain confluent cells. All cells were cultured at $37{ }^{\circ} \mathrm{C}$ under $10 \% \mathrm{CO}_{2}$ and $90 \%$ moist air. Media were changed twice a week. The viability of ARPE-19 cells after incubation was assessed using trypan blue dye.

Total RNA extraction and MCP-1 and IL-8 mRNA expression by real-time polymerase chain reaction

Berberine was purchased from Sigma Chemicals (St. Louis, Mo., USA). The molecular weight of the alkaloid was 371.8 , and the chemical structure is shown in Fig. 1. Berberine was dissolved in $50 \mathrm{mM}$ dimethyl sulfoxide (DMSO) just before use. The final concentration of DMSO was kept at $\leq 0.05 \%$ in the culture media to avoid its inhibitory effects on the proliferation of the ARPE-19 cell line.

ARPE-19 cells were planted and cultured in 6-well culture plates (averaging $2.0 \times 10^{6}$ cells/well) for 14 days in DMEM/F 12 medium containing $10 \%$ FBS. After the cells were washed twice with serum-free medium, ARPE-19 cells were preincubated for $2 \mathrm{~h}$ in serum-free medium with $0.05 \%$ DMSO or $0.2,1,5$, and $25 \mu \mathrm{M}$ of berberine for $30 \mathrm{~min}$. Then, LPS (Escherichia coli, serotype 055:B5, Sigma-Aldrich, St Louis, Mo., USA) was added to the medium and incubated. Total RNA was extracted from the cells using RNeasy Protect Mini Kit (Qiagen, Hilden, Germany) and treated with RNase-free DNase Set (Qiagen, Hilden, Germany) to remove any residual genomic DNA. One microgram of each total RNA was reverse transcribed using random hexamers, MultiScribe reverse transcriptase (Applied Biosystems, Branchburg, NJ, USA), and thermal cycler (Gene Amp PCR System 2400; Applied Biosystems, 
Norwalk, CT, USA). Condition of the reverse transcription included incubation at $25^{\circ} \mathrm{C}$ for $10 \mathrm{~min}$, reverse transcription at $48{ }^{\circ} \mathrm{C}$ for $30 \mathrm{~min}$, and reverse transcriptase inactivation at $95{ }^{\circ} \mathrm{C}$ for $5 \mathrm{~min}$.

cDNA was used to detect real-time PCR products for MCP-1 and IL-8 using TaqMan Universal Master Mix (Applied Biosystems, Branchburg, NJ, USA) and ABI PRISM $^{\mathrm{TM}} 7700$ Sequence Detector (Applied Biosystems, Foster, CA, USA) with TaqMan ${ }^{\circledR}$ Pre-Developed Assay Reagents (Applied Biosystems, Foster, CA, USA) for human MCP-1 and IL-8. The thermal profile for each primer consisted of $2 \mathrm{~min}$ at $50{ }^{\circ} \mathrm{C}$ and $10 \mathrm{~min}$ at $95{ }^{\circ} \mathrm{C}$, followed by 40 cycles of $15 \mathrm{~s}$ at $95^{\circ} \mathrm{C}$ and $1 \mathrm{~min}$ at $60^{\circ} \mathrm{C}$. To compare expression patterns, mRNA template concentrations for glyceraldehyde-3phosphate dehydrogenase (GAPDH) and the target genes were calculated using the standard curve method. The expression levels of MCP-1 and IL- 8 mRNA were normalized by GAPDH mRNA level in each sample, and the changes were expressed as an $n$-fold relative to the value of cells untreated with LPS.

MCP-1 and IL-8 protein concentrations

by enzyme-linked immunosorbent assay (ELISA)

ARPE-19 cells were seeded in 24-well culture plates (averaging $2.0 \times 10^{5}$ cells/well) and incubated for 14 days in DMEM/ $\mathrm{F}_{12}$ medium containing $10 \%$ FBS. The cells were washed twice with serum-free medium and incubated in serum-free medium for $2 \mathrm{~h}$. ARPE19 cells were preincubated in serum-free medium with $0.05 \%$ DMSO or $0.2,1,5$, and $25 \mu \mathrm{M}$ of berberine for $30 \mathrm{~min}$. Then, LPS was added to the medium, and it was incubated for $24 \mathrm{~h}$. Thereafter, the supernatant was collected and stored at $-70{ }^{\circ} \mathrm{C}$ until assay. MCP1 and IL-8 protein concentrations were determined using ELISA (Amersham Biosciences, Little Chalfont, Buckinghamshire, UK) and were calculated based on standard curves using concentrations of recombinant $\mathrm{MCP}-1$ and $\mathrm{IL}-8$ in the ranges of 51-2000 and 25-1000 pg/ml, respectively. All assays were performed in duplicate.

Statistical analysis

The results were expressed as mean values \pm standard errors. Statistical analysis was performed using the Scheffe's procedure for multiple comparisons of mean value. $P<0.05$ was considered statistically significant.

\section{Results}

Expression of MCP-1 mRNA and IL-8 mRNA after stimulation with LPS in ARPE-19 cells

Cell viability was above $98 \%$; most ARPE-19 cells incubated with LPS $(5 \mu \mathrm{g} / \mathrm{ml}), 0.05 \%$ DMSO, and berberine $(25 \mu \mathrm{M})$ for $24 \mathrm{~h}$ were viable.

When the medium was incubated with $0.05 \%$ DMSO, ARPE-19 cells expressed small amounts of MCP-1 mRNA and IL-8 mRNA. After stimulation with LPS $(1 \mu \mathrm{g} / \mathrm{ml})$ and $0.05 \%$ DMSO, MCP-1 mRNA (Fig. 2a) and IL-8 mRNA (Fig. 2b) in ARPE-19 cells increased, reached maximum levels (28.4- and 18.3fold, respectively) at $3 \mathrm{~h}$, and then gradually decreased. Berberine $(25 \mu \mathrm{M})$ inhibited these mRNA expressions in ARPE-19 cells (Fig. 2a, b).

LPS $(0.2-5 \mu \mathrm{g} / \mathrm{ml})$ dose-dependently stimulated MCP-1 mRNA (Fig. 3a) and IL-8 mRNA (Fig. 3b) in ARPE-19 cells. Berberine $(25 \mu \mathrm{M})$ inhibited these mRNA expressions in ARPE-19 cells (Fig. 3a, b).
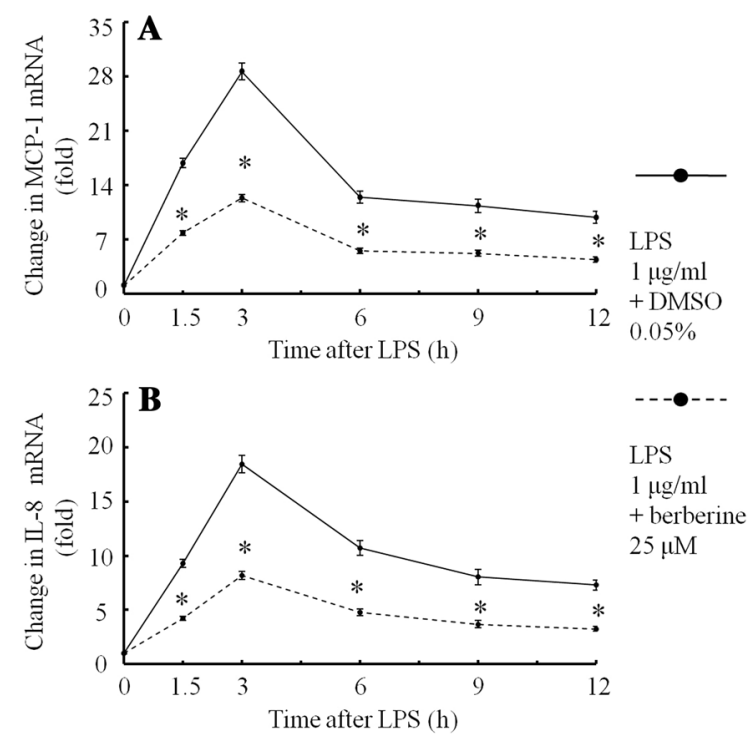

Fig. 2 Changes in MCP-1 mRNA and IL-8 mRNA expression after stimulation with LPS in ARPE-19 cells in serum-free media were preincubated for $30 \mathrm{~min}$ with berberine $(25 \mu \mathrm{M})$ or $0.05 \%$ DMSO. After LPS $(1 \mu \mathrm{g} / \mathrm{ml})$ had been added to the medium, ARPE-19 cells were incubated for $1.5,3,6,9$, and $12 \mathrm{~h}$. The changes in mRNA were determined using real-time PCR. Changes in MCP-1 mRNA (a) and IL-8 mRNA (b) after stimulation with LPS are shown. The data are expressed as means \pm standard errors of four independent experiments. $* P<0.01$, compared to the value without berberine 
Incubation with DMSO $0.05 \%$ had only a little inhibition on MCP-1 (Fig. 4a) and IL-8 mRNA (Fig. 4b). Berberine $(1-25 \mu \mathrm{M})$ dose-dependently inhibited MCP-1 mRNA (Fig. 4a) and IL-8 mRNA (Fig. 4b) in the cells stimulated with LPS $(1 \mu \mathrm{g} / \mathrm{ml})$ at $3 \mathrm{~h}$. Berberine at $25 \mu \mathrm{M}$ showed maximum inhibition: MCP-1 and IL-8 mRNA expression, 12.2- and 8.2fold, respectively.

MCP-1 and IL-8 protein concentrations after stimulation with LPS in ARPE-19 cells

When the cells were incubated for $24 \mathrm{~h}$ with $0.05 \%$ DMSO, MCP-1 and IL-8 protein concentrations in the culture media were 147 and $131 \mathrm{pg} / \mathrm{ml}$, respectively. After stimulation with LPS $(1 \mu \mathrm{g} / \mathrm{ml})$ and $0.05 \%$ DMSO, MCP-1 (Fig. 5a) and IL-8 (Fig. 5b) in the culture media increased and reached maximum levels (4514 and $3529 \mathrm{pg} / \mathrm{ml}$, respectively) at $24 \mathrm{~h}$, and remained so at $30 \mathrm{~h}$. Berberine $(25 \mu \mathrm{M})$ inhibited these protein levels (Fig. 5a, b).
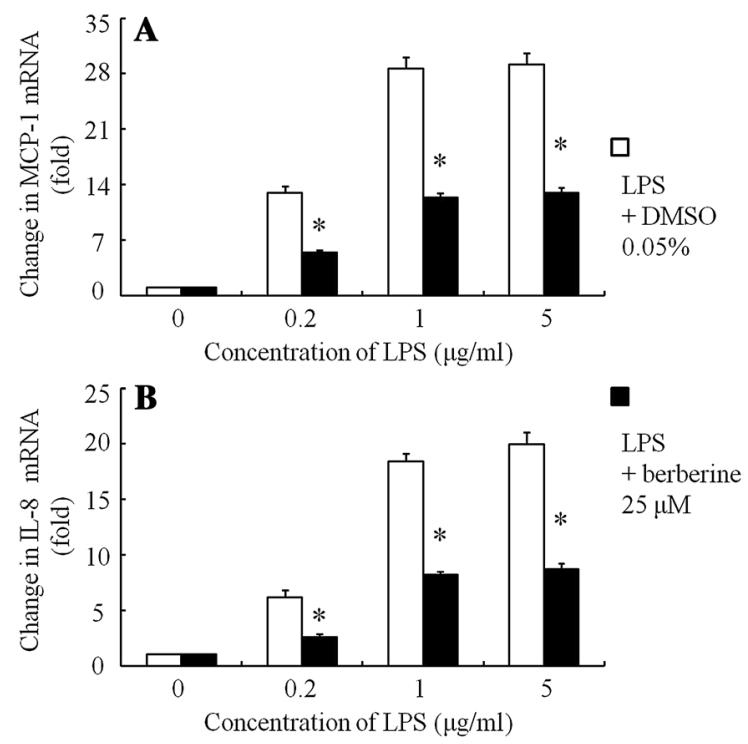

Fig. 3 Changes in MCP-1 mRNA and IL-8 mRNA expression after stimulation with various concentrations of LPS in ARPE19 cells in serum-free media were preincubated for 30 min with berberine $(25 \mu \mathrm{M})$ or $0.05 \%$ DMSO. After various concentrations of LPS $(0.5,1$ and $5 \mu \mathrm{g} / \mathrm{ml})$ had been added to the medium, the cells were incubated for $3 \mathrm{~h}$. The changes in mRNA were determined using real-time PCR. Changes in MCP-1 mRNA (a) and IL-8 mRNA (b) after stimulation with LPS are shown. The data are expressed as means \pm standard errors of four independent experiments. $* P<0.01$, compared to the value without berberine
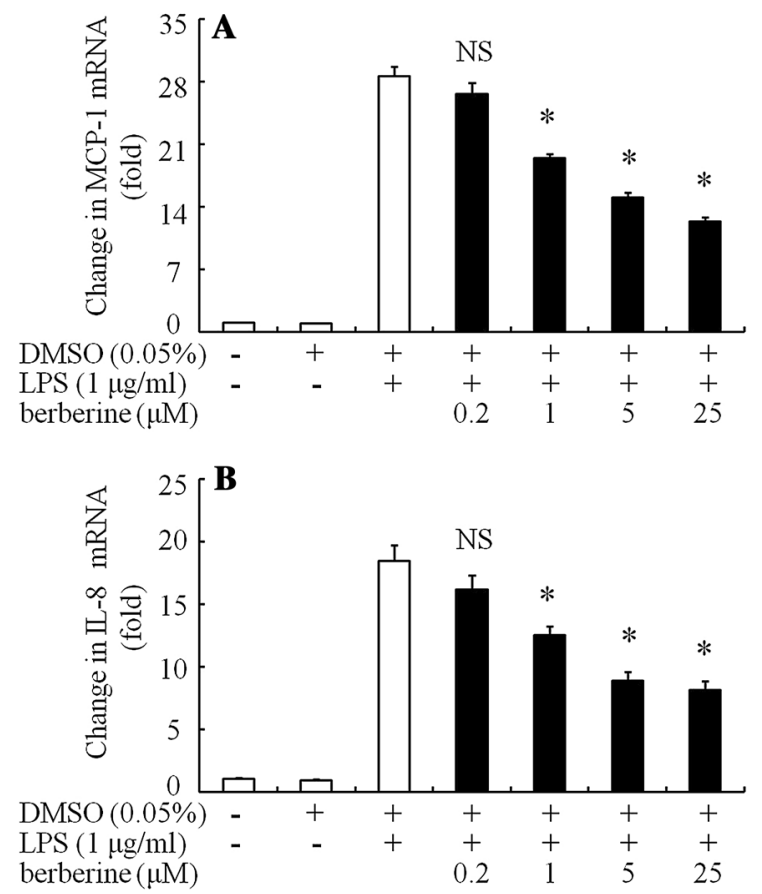

Fig. 4 Effects of berberine on MCP-1 mRNA and IL-8 mRNA expression after stimulation with LPS in ARPE-19 cells in serum-free media were preincubated for $30 \mathrm{~min}$ with berberine or $0.05 \%$ DMSO. LPS $(1 \mu \mathrm{g} / \mathrm{ml})$ was added to the media and incubated for $3 \mathrm{~h}$. After incubation, total RNA was extracted from the ARPE-19 cells, and semiquantitative real-time PCR was performed. Changes in MCP-1 mRNA (a) and IL-8 mRNA (b) in ARPE-19 cells after stimulation with LPS for $3 \mathrm{~h}$ are shown. The data are expressed as means \pm standard errors of four independent experiments. ${ }^{*} P<0.01 ; N S$ not significant, compared to the value of LPS-alone-treated group

DMSO $0.05 \%$ had only a little inhibition on IL-8 and MCP-1 protein levels in the media (Fig. 6). Berberine (1-25 $\mu \mathrm{M})$ dose-dependently inhibited LPS-stimulated MCP-1 (Fig. 6a) and IL-8 (Fig. 6b) concentrations in the culture medium at $24 \mathrm{~h}$. Berberine at $25 \mu \mathrm{M}$ showed maximum inhibition: MCP-1 and IL-8 protein levels, $1182 \mathrm{pg} / \mathrm{ml}$ (inhibition of 73.8\%) and $1034 \mathrm{pg} /$ $\mathrm{ml}$ (inhibition of $70.7 \%$ ), respectively.

\section{Discussion}

Dunn et al. [13] have demonstrated changes in gene expression and function with time of confluence in ARPE-19 cells with a mature epithelial phenotype require as much as 2-4 weeks of culture. In the present study, therefore, ARPE-19 cells cultured for 14 days after planting were used. 

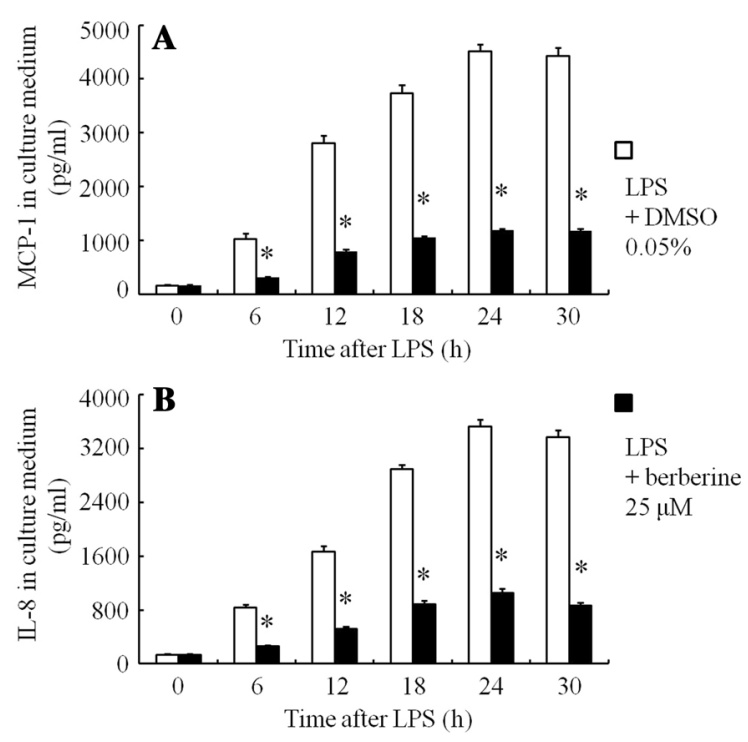

Fig. 5 Changes in MCP-1 and IL-8 protein concentrations in culture medium of ARPE-19 cells in serum-free media were preincubated for $30 \mathrm{~min}$ with berberine or $0.05 \%$ DMSO. After LPS $(1 \mu \mathrm{g} / \mathrm{ml})$ had been added to the medium, the cells were incubated for $6,12,18,24$, and $30 \mathrm{~h}$. The MCP-1 levels (a) and IL-8 concentrations (b) in the culture media after stimulation with LPS, determined using ELISA, are shown. The data are expressed as means \pm standard errors of four independent experiments. $* P<0.01$, compared to the value without berberine

In the our present findings, $0.2,1$, and $5 \mu \mathrm{g} / \mathrm{ml} \mathrm{LPS}$ dose-dependently stimulated MCP-1 mRNA and IL- 8 mRNA, and $5 \mu \mathrm{g} / \mathrm{ml}$ LPS showed had no significant difference compared with $1 \mu \mathrm{g} / \mathrm{ml}$ LPS in ARPE-19 cells. Therefore, the inhibitory effects of berberine were determined after stimulation of $1 \mu \mathrm{g} / \mathrm{ml}$ LPS in the present study. In the present study, after stimulation with LPS $(1 \mu \mathrm{g} / \mathrm{ml})$, MCP- 1 and IL- 8 mRNA in ARPE-19 cells reached peak levels at $3 \mathrm{~h}$, and MCP-1 and IL- 8 protein in the culture media reached peak levels at $24 \mathrm{~h}$. Therefore, the inhibitory effects of berberine on the MCP-1 and IL- 8 mRNA were determined after stimulation of LPS at $3 \mathrm{~h}$, and on the MCP-1 and IL- 8 protein were determined after stimulation of LPS at $24 \mathrm{~h}$.

In the present study, LPS dose-dependently stimulated MCP-1 and IL-8 expression in ARPE-19 cells. High levels of the MCP-1 and IL- 8 in the aqueous humor and vitreous were involved in part in the pathogenesis of intraocular disorders such as agerelated macular degeneration, proliferative vitreoretinal diseases, and diabetic retinopathy [18-25].
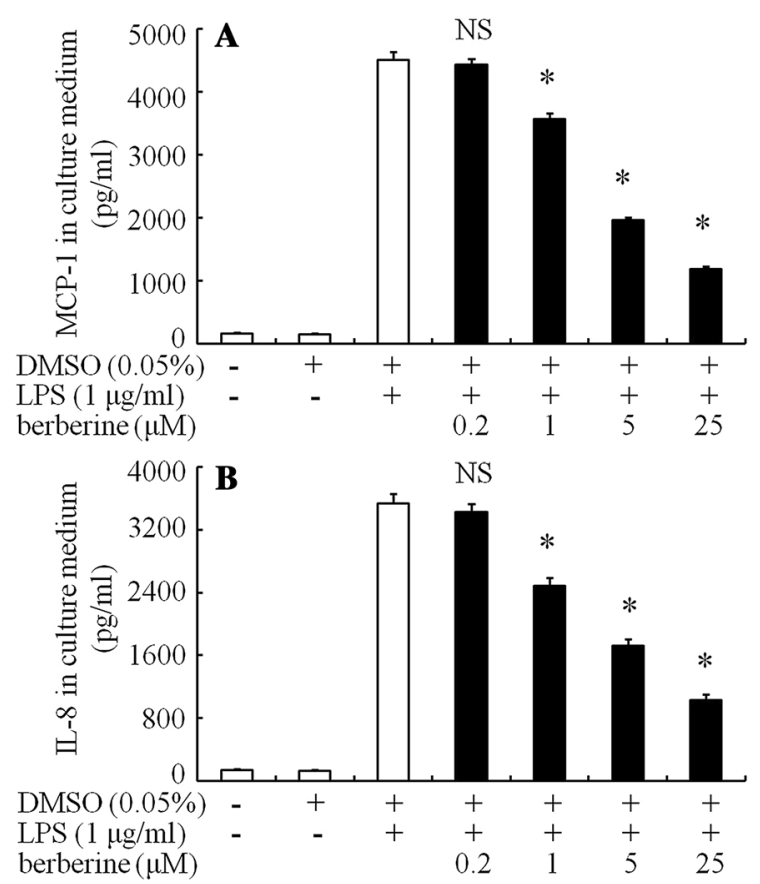

Fig. 6 Effects of berberine on MCP-1 and IL-8 protein concentrations after stimulation with LPS in ARPE-19 cells were incubated for $30 \mathrm{~min}$ in serum-free media with berberine or $0.05 \%$ DMSO. LPS $(1 \mu \mathrm{g} / \mathrm{ml})$ was added to the medium and the cells were incubated for $24 \mathrm{~h}$. The MCP-1 levels (a) and IL-8 protein concentrations (b) after stimulation with LPS in the culture media, determined using ELISA, are shown. The data are expressed as means \pm standard errors of four independent experiments. ${ }^{*} P<0.01 ; N S$ not significant, compared to the value of LPS-alone-treated group

Therefore, the treatment of these eye diseases requires the suppression of MCP-1 and IL-8 expression.

In China, berberine (5-20 mg/kg per day) has long been used in the treatment of diarrhea and gastrointestinal disorders [27, 28]. In Japan, berberine alone is not used clinically. Mixed extracts from multiple herbs, which contain several alkaloids, are administered orally. For example, Oren-gedoku-to (HuangLian-Jie-Du-Tang in Chinese), which contains extracts from Scutellariae sp. radix, Coptidis sp. rhizoma, Gardeniae sp. fructus, and Phellodendri sp. cortex, is prescribed for treatment of gastritis. Orengedoku-to $(1.5 \mathrm{~g})$ usually contains berberine (240 mg). Kong et al. [42] reported that oral administration of berberine $(0.5 \mathrm{~g}$ twice per day) for 3 months lowers serum low-density lipoprotein cholesterol in hypercholesterolemic people. The alkaloid also reported has the other pharmacological actions, including glucose-lowering potential [44-47]. 
We previously reported that berberine inhibited the in vivo expression of MCP-1 and IL- 8 induced by LPS, decreasing the inflammatory cell infiltration and the levels of protein and cells in the aqueous humor in rat [36]. In the present study, we found that the alkaloid significantly inhibited the in vitro expression of MCP-1 and IL- 8 induced by LPS in a human retinal pigment epithelial cell line. Therefore, an effect of berberine in the chemokine-mediated disorders may be expected.

Acknowledgements This work was supported by Zhejiang Province Traditional Chinese Medicine Science and Technology Planning Project (No. 2016ZA132), and by Zhejiang Province Medical and Health Science and Technology Project (No. 2014KYA104).

\section{Compliance with ethical standards}

Conflict of interest The authors declare that they have no competing interests.

Open Access This article is distributed under the terms of the Creative Commons Attribution 4.0 International License (http:// creativecommons.org/licenses/by/4.0/), which permits unrestricted use, distribution, and reproduction in any medium, provided you give appropriate credit to the original author(s) and the source, provide a link to the Creative Commons license, and indicate if changes were made.

\section{References}

1. Bok D (1993) The retinal pigment epithelium: a versatile partner in vision. J Cell Sci Suppl 17:189-195

2. Hanus J, Anderson C, Wang S (2015) RPE necroptosis in response to oxidative stress and in AMD. Ageing Res Rev 24(Pt B):286-298. doi:10.1016/j.arr.2015.09.002

3. Hanus J, Anderson C, Sarraf D, Ma J, Wang S (2016) Retinal pigment epithelial cell necroptosis in response to sodium iodate. Cell Death Discov 2:16054. doi:10.1038/ cddiscovery. 2016.54

4. NagasakaY Kaneko H, Ye F, Kachi S, Asami T, Kato S, Takayama K, Hwang SJ, Kataoka K, Shimizu H, Iwase T, Funahashi Y, Higuchi A, Senga T, Terasaki H (2017) Role of caveolin-1 for blocking the epithelial-mesenchymal transition in proliferative vitreoretinopathy. Invest Ophthalmol Vis Sci 58:221-229. doi:10.1167/iovs.16-20513

5. Simó R, Villarroel M, Corraliza L, Hernández C, GarciaRamírez M (2010) The retinal pigment epithelium: something more than a constituent of the blood-retinal barrierimplications for the pathogenesis of diabetic retinopathy. J Biomed Biotechnol 2010:190724. doi:10.1155/2010/ 190724

6. Mai K, Chui JJ, Di Girolamo N, McCluskey PJ, Wakefield D (2014) Role of toll-like receptors in human iris pigment epithelial cells and their response to pathogen-associated molecular patterns. J Inflamm (Lond) 11:20. doi:10.1186/ 1476-9255-11-20

7. Leung KW, Barnstable CJ, Tombran-Tink J (2009) Bacterial endotoxin activates retinal pigment epithelial cells and induces their degeneration through IL-6 and IL-8 autocrine signaling. Mol Immunol 46:1374-1386. doi:10.1016/j. molimm.2008.12.001

8. Rollins BJ, Walz A, Baggiolini M (1991) Recombinant human MCP-1/JE induces chemotaxis, calcium flux, and the respiratory burst in human monocytes. Blood 78:1112-1116

9. Larsen CG, Anderson AO, Appella E, Oppenheim JJ, Matsushima K (1989) The neutrophil-activating protein (NAP-1) is also chemotactic for T lymphocytes. Science 243:1464-1466

10. Baggiolini M, Dewald B, Moser B (1994) Interleukin-8 and related chemotactic cytokines-CXC and CC Chemokines. Adv Immunol 55:97-179

11. Zlotnit A, Yoshie O (2000) Chemokines: a new classification system and their role in immunity. Immunity 12:121-127

12. Crane IJ, Wallace CA, Mckillop-Smith S, Forrester JV (2000) Control of chemokine production at the blood-retina barrier. Immunology 101:426-433

13. Dunn KC, Aotaki-Keen AE, Putkey FR, Hjelmeland LM (1996) ARPE-19, a human retinal pigment epithelial cell line with differentiated properties. Exp Eye Res 62:155-169

14. Cui HS, Hayasaka S, Zhang XY, Chi ZL, Hayasaka Y (2005) Effects of $\alpha$-melanocyte-stimulating hormone on interleukin-8 and monocyte chemotactic protein-1 expression in a human retinal pigment epithelial cell line. Ophthalmic Res 37:279-288

15. Cui HS, Hayasaka S, Zhang XY, Hayasaka Y, Chi ZL, Zheng LS (2006) Effect of berberine on interleukin-8 and monocyte chemotactic protein-1 expression in a human retinal pigment epithelial cell line. Ophthalmic Res 38:149-157

16. Pollreisz A, Rafferty B, Kozarov E, Lalla E (2012) Klebsiella pneumoniae induces an inflammatory response in human retinal-pigmented epithelial cells. Biochem Biophys Res Commun 418:33-37. doi:10.1016/j.bbrc.2011.12.102

17. Paeng SH, Park WS, Jung WK, Lee DS, Kim GY, Choi YH, Seo SK, Jang WH, Choi JS, Lee YM, Park S, Choi IW (2015) YCG063 inhibits Pseudomonas aeruginosa LPS-induced inflammation in human retinal pigment epithelial cells through the TLR2-mediated AKT/NF- $\mathrm{BB}$ pathway and ROS-independent pathways. Int J Mol Med 36:808-816. doi:10.3892/ijmm.2015.2266

18. Du Z, Wu X, Song M, Li P, Wang L (2016) Oxidative damage induces MCP-1 secretion and macrophage aggregation in age-related macular degeneration (AMD). Graefes Arch Clin Exp Ophthalmol 254:2469-2476

19. Hautamäki A, Seitsonen S, Holopainen JM, Moilanen JA, Kivioja J, Onkamo P, Järvelä I, Immonen I (2015) The genetic variant rs $4073 \mathrm{~A} \rightarrow \mathrm{T}$ of the Interleukin- 8 promoter region is associated with the earlier onset of exudative agerelated macular degeneration. Acta Ophthalmol 93:726-733. doi:10.1111/aos.12799

20. Jonas JB, Tao Y, Neumaier M, Findeisen P (2012) Cytokine concentration in aqueous humour of eyes with exudative 
age-related macular degeneration. Acta Ophthalmol 90:e381-e388. doi:10.1111/j.1755-3768.2012.02414.x

21. Mitamura Y, Takeuchi S, Yamamoto S, Yamamoto T, Tsukahara I, Matsuda A, Tagawa Y, Mizue Y, Nishihira J (2002) Monocyte chemotactic protein-1 levels in the vitreous of patients with proliferative vitreoretinopathy. Jpn J Ophthalmol 46:218-221

22. Aksunger A, Or M, Okur H, Hasanreisoglu B, Akbatur H (1997) Role of interleukin 8 in the pathogenesis of proliferative vitreoretinopathy. Ophthalmologica 211:223-225

23. Harada C, Okumura A, Namekata K, Nakamura K, MitamuraY Ohguro H, Harada T (2006) Role of monocyte chemotactic protein-1 and nuclear factor kappa B in the pathogenesis of proliferative diabetic retinopathy. Diabetes Res Clin Pract 74:249-256

24. Petrovic MG, Korosec P, Kosnik M, Hawlina M (2007) Vitreous levels of interleukin-8 in patients with proliferative diabetic retinopathy. Am J Ophthalmol 143:175-176

25. Hayasaka S, Zhang XY, Cui HS, Yanagisawa S, Chi ZL, Shimada Y (2006) Vitreous chemokines and Sho (Zheng in Chinese) of Chinese-Korean-Japanese medicine in patients with diabetic vitreoretinopathy. Am J Chin Med 34:537-543

26. Gerszten RE, Garcia-Zepeda EA, Lim YC, Yoshida M, Ding HA, Gimbrone MA Jr, Luster AD, Luscinskas FW, Rosenzweig A (1999) MCP-1 and IL-8 trigger firm adhesion of monocytes to vascular endothelium under flow conditions. Nature 398:718-723

27. Chen C, Yu Z, Li Y, Fichna J, Storr M (2014) Effects of berberine in the gastrointestinal tract-a review of actions and therapeutic implications. Am J Chin Med 42:1053-1070. doi:10.1142/S0192415X14500669

28. Chen C, Tao C, Liu Z, Lu M, Pan Q, Zheng L, Li Q, Song Z, Fichna J (2015) A randomized clinical trial of berberine hydrochloride in patients with diarrhea predominant irritable bowel syndrome. Phytother Res 29:1822-1827. doi:10.1002/ptr.5475

29. Subbaiah TV, Amin AH (1967) Effect of berberine sulphate on entamoeba histolytica. Nature 215:527-528

30. Kuo CL, Chi CW, Liu TY (2004) The anti-inflammatory potential of berberine in vitro and in vivo. Cancer Lett 203:127-137

31. Choi SB, Bae GS, Jo IJ, Wang S, Song HJ, Park SJ (2016) Berberine inhibits inflammatory mediators and attenuates acute pancreatitis through deactivation of JNK signaling pathways. Mol Immunol 74:27-38. doi:10.1016/j.molimm. 2016.04.011

32. Lin K, Liu S, Shen Y, Li Q (2013) Berberine attenuates cigarette smoke-induced acute lung inflammation. Inflammation 36:1079-1086. doi:10.1007/s10753-013-9640-0

33. Cheng WE, Ying Chang M, Wei JY, Chen YJ, Maa MC, Leu TH (2015) Berberine reduces Toll-like receptor-mediated macrophage migration by suppression of Src enhancement. Eur J Pharmacol 757:1-10. doi:10.1016/j. ejphar.2015.03.013

34. Hayasaka S, Kodama T, Ohira A (2012) Traditional Japanese herbal (kampo) medicines and treatment of ocular diseases: a review. Am J Chin Med 40:887-904. doi:10. 1142/S0192415X12500668
35. Yang Y, Wang Q, Xie M, Liu P, Qi X, Liu X, Li Z (2017) Berberine exerts an anti-inflammatory role in ocular Behcet's disease. Mol Med Rep 15:97-102. doi:10.3892/mmr. 2016.5980

36. Cui HS, Hayasaka S, Zheng LS, Hayasaka Y, Zhang XY, Chi ZL (2007) Effect of berberine on monocyte chemotactic protein-1 and cytokine-induced neutrophil chemoattractant1 expression in rat lipopolysaccharide-induced uveitis. Ophthalmic Res 39:32-39

37. Liu C, Wang Z, SongY WuD, Zheng X, Li P, Jin J, Xu N, Li L (2015) Effects of berberine on amelioration of hyperglycemia and oxidative stress in high glucose and high fat diet-induced diabetic hamsters in vivo. Biomed Res Int 2015:313808. doi:10.1155/2015/313808

38. Zhang Y, Li X, Zou D, Liu W, Yang J, Zhu N, Huo L, Wang M, Hong J, Wu P, Ren G, Ning G (2008) Treatment of type 2 diabetes and dyslipidemia with the natural plant alkaloid berberine. J Clin Endocrinol Metab 93:2559-2565. doi:10.1210/jc.2007-2404

39. Zhang H, Wei J, Xue R, Wu JD, Zhao W, Wang ZZ, Wang SK, Zhou ZX, Song DQ, Wang YM, Pan HN, Kong WJ, Jiang JD (2010) Berberine lowers blood glucose in type 2 diabetes mellitus patients through increasing insulin receptor expression. Metabolism 59:285-292. doi:10.1016/ j.metabol.2009.07.029

40. Pirillo A, Catapano AL (2015) Berberine, a plant alkaloid with lipid- and glucose-lowering properties: from in vitro evidence to clinical studies. Atherosclerosis 243:449-461. doi:10.1016/j.atherosclerosis.2015.09.032

41. Li XY, Zhao ZX, Huang M, Feng R, He CY, Ma C, Luo SH, Fu J, Wen BY, Ren L, Shou JW, Guo F, Chen Y, Gao X, Wang Y, Jiang JD (2015) Effect of berberine on promoting the excretion of cholesterol in high-fat diet-induced hyperlipidemic hamsters. J Transl Med 13:278. doi:10.1186/ s12967-015-0629-3

42. Kong W, Wei J, Abidi P, Lin M, Inaba S, Li C, Wang Y, Wang Z, Si S, Pan H, Wang S, Wu J, Wang Y, Li Z, Liu J, Jiang JD (2004) Berberine is a novel cholesterol-lowering drug working through a unique mechanism distinct from statins. Nature Med 10:1344-1351

43. Li YH, Yang P, Kong WJ, Wang YX, Hu CQ, Zuo ZY, Wang YM, Gao H, Gao LM, Feng YC, Du NN, Liu Y, Song DQ, Jiang JD (2009) Berberine analogues as a novel class of the low-density-lipoprotein receptor up-regulators: synthesis, structure-activity relationships, and cholesterol-lowering efficacy. J Med Chem 52:492-501. doi:10.1021/ jm801157z

44. Cui HS, Matsumoto K, Murakami Y, Hori H, Zhao Q, Obi R (2009) Berberine exerts neuroprotective actions against in vitro ischemia-induced neuronal cell damage in organotypic hippocampal slice cultures: involvement of B-cell lymphoma 2 phosphorylation suppression. Biol Pharm Bull 32:79-85

45. de Oliveira JS, Abdalla FH, Dornelles GL, Adefegha SA, Palma TV, Signor C, da Silva Bernardi J, Baldissarelli J, Lenz LS, Magni LP, Rubin MA, Pillat MM, de Andrade CM (2016) Berberine protects against memory impairment and anxiogenic-like behavior in rats submitted to sporadic Alzheimer'slike dementia: involvement of acetylcholinesterase and cell 
death. Neurotoxicology 57:241-250. doi: 10.1016/j.neuro. 2016.10.008

46. Zhou J, Du X, Long M, Zhang Z, Zhou S, Zhou J, Qian G (2016) Neuroprotective effect of berberine is mediated by MAPK signaling pathway in experimental diabetic neuropathy in rats. Eur J Pharmacol 774:87-94. doi:10.1016/j. ejphar.2016.02.007
47. Kumar A, Ekavali Mishra J, Chopra K, Dhull DK (2016) Possible role of P-glycoprotein in the neuroprotective mechanism of berberine in intracerebroventricular streptozotocin-induced cognitive dysfunction. Psychopharmacology 233:137-152. doi:10.1007/s00213-015-4095-7 